Journal of Business Finance and Economic (JBFE)

Volume 1, Nomor 1, Juni 2020

http://journal.univetbantara.ac.id/index.php/jbfe

\title{
Dampak Pemimpin Etis, Efektivitas Pemimpin, dan Stress Kerja terhadap Niat Berpindah Karyawan
}

\author{
Egal Radhika Maulana ${ }^{1}$ \\ Bambang Nur Cahyaningrum² \\ Ariyani Wahyu Wijayanti ${ }^{3}$ \\ Fakultas Ekonomi, Universitas Veteran Bangun Nusantara ${ }^{\mathbf{1 2 3}}$ \\ egalradhika027@gmail.com¹ \\ bambangnurcahyaningrum@gmail.com² \\ aryn.3d071208@gmail.com³
}

\begin{abstract}
The purpose of this study is to examine and analyze the impact of ethical leaders, leader effectiveness, and work stress on the intention to move employees of CV Rimba Sentosa Tawangsari. The sample in this study was 115 employees of CV Rimba Sentosa Tawangsari. The sampling method used is nonprobability sampling, while the sampling technique used is convenience sampling. Testing the hypothesis in this study using SEM (Structural Equation Modeling) analysis. The results of this study, showed that the ethical leader variable and the effectiveness of the leader, had no effect on work stress. The variable of ethical leader and work stress, does not affect employee intention to move. The leader effectiveness variable has a significant effect on employee turnover intentions.
\end{abstract}

Keywords: Ethical leader, leader effectiveness, work stress, employee turnover intentions.

\section{PENDAHULUAN}

Sumber daya manusia sangat penting dimiliki oleh suatu perusahaan, karena keberhasilan organisasi atau perusahaan sangat ditentukan oleh unsur manusia (Ardana, et al, 2012). Agar dapat unggul dalam persaingan, maka pengelolaan sumber daya manusia harus dapat berjalan dengan baik, sehingga perusahaan mampu bersaing dengan para kompetitornya. Jika pengelolaan sumber daya manusia tidak berjalan dengan efektif, maka akan muncul berbagai masalah yang akan mengganggu kinerja perusahan (Khoiroh, 2012). Salah satu bentuk perilaku karyawan akibat kegagalan perusahaan mengelola sumber daya manusia yang dimilikinya adalah keinginan untuk 
Journal of Business Finance and Economic (JBFE)

Volume 1, Nomor 1, Juni 2020

http://journal.univetbantara.ac.id/index.php/jbfe

berpindah kerja (turnover intention) yang berujung pada keputusan karyawan untuk meninggalkan pekerjaannya.

Pengunduran diri karyawan berkaitan dengan kualitas manajemen sumber daya manusia pada perusahaan, yang menjadi indikator ekonomisasi (penghematan), efisiensi (daya guna), dan efektifitas (hasil guna) kegiatan operasional perusahaan (Ningrum, et al, 2014). Turnover intention dapat didefinisikan sebagai kecenderungan atau niat karyawan untuk berhenti bekerja dari pekerjaannya secara sukarela menurut pilihannya sendiri (Zeffane dan Putriani, 2014). Tet dan Mayer dalam Ridlo (2012), telah memberikan definisi intention to leave atau turnover intention, yaitu niat karyawan untuk meninggalkan organisasi dengan sadar dan sengaja oleh karyawan untuk meninggalkan organisasi. Sedangkan menurut Sudiro (2011), "Perputaran karyawan adalah tingkat perpindahan (movement) atau keluar dari keanggotaan sebuah organisasi. Dalam arti yang luas, turnover diartikan sebagai tingkat atau besarnya karyawan yang masuk dan keluar dari perusahaan.”

Fenomena turnover intention atau niat berpindah karyawan, juga terjadi pada salah satu perusahaan di daerah kecamatan Tawangsari yang bergerak di bidang mebel, perusahaan tersebut adalah CV Rimba Sentosa Tawangsari. Menurut data yang dikemukakan oleh Bapak Kariawan (Manajer Personalia CV Rimba Sentosa Tawangsari), bahwa pada tahun 2016 karyawan yang keluar dari perusahaan berjumlah 8 orang, tahun 2017 sebanyak 13 karyawan, tahun 2018 sebanyak 19 karyawan. Dari data tersebut dapat disimpulkan bahwa setiap tahun terdapat peningkatan niat berpindah karyawan di CV Rimba Sentosa Tawangsari.

Berbagai faktor yang mempengaruhi keinginan karyawan untuk meninggalkan organisasi atau perusahaan antara lain pemimpin etis, efektivitas pemimpin dan stres kerja. Handoko (2010) mengemukakan stres adalah suatu kondisi ketegangan yang mempengaruhi emosi, proses berfikir dan kondisi seseorang. Stres di tempat kerja akhirakhir ini telah menjadi masalah yang serius bagi manajemen perusahaan di dalam dunia bisnis (Qureshi et al., 2013). Karyawan sering dihadapkan dengan berbagi masalah dalam perusahaan sehingga sangat mungkin untuk terkena stres. Studi penelitian sebelumnya yang dilakukan oleh Paille (2011), menunjukkan bahwa stres kerja mampu menurunkan kondisi fisik seseorang di tempat kerja, meningkatkan tekanan psikologis di tempat kerja, mendorong kekerasan antar rekan kerja dan menyebabkan kelelahan yang berlebihan. Stres kerja akan muncul apabila di suatu titik kondisi karyawan merasa tidak dapat lagi memenuhi tuntutan-tuntutan pekerjaan. Karyawan yang tidak dapat 
Journal of Business Finance and Economic (JBFE)

Volume 1, Nomor 1, Juni 2020

http://journal.univetbantara.ac.id/index.php/jbfe

menahan stres kerja dalam jangka panjang, akan membuat karyawan tersebut tidak akan mampu lagi bekerja di perusahaan yang bersangkutan. Pada tahap yang semakin parah, stres bisa membuat karyawan menjadi sakit atau bahkan akan mengundurkan diri dari pekerjaannya (Manurung \& Ratnawati, 2012).

Pemimpin yang efektif merupakan salah satu faktor penting yang mempengaruhi cara kerja pegawai, yang akan menjadi kepuasan kerja, yang dapat berdampak pada hasil kerja yang diberikan oleh pegawai (Astuti, 2009). Efektivitas pemimpin ditunjukkan dari profesionalisme seorang pemimpin yang sesuai dengan posisi dan eksistensi organisasinya, pemimpin dituntut menguasai berbagai aspek manajerial yang berkaitan dengan perilaku organisasinya, karena dengan memahami aspek manajerial tersebut, dapat digunakan untuk menopang tugas utama dalam pemimpin, baik dalam berpikir secara konsepsional, membina kreativitas, mewujudkan kondisi organisasi yang harmonis, maupun ketika mengintegrasikan antara aspek-aspek struktur, proses, teknologi dan manusia (Sujak, 2009).

Pemimpin etis, bukan hanya membimbing karyawan dalam perusahaan saja, tetapi juga para pemegang saham dan mampu mencapai tujuan perusahaan (Elci Meral et al., 2012), dan mereka menjadi panutan bagi para bawahannnya (Watson, 2010). Trevino, et al,. (2010) mendefinisikan kepemimpinan etis sebagai "sebuah konsep relasional, yaitu dibangun di dalam dan melalui interaksi sosial dengan bawahan”. Hasil penelitian Ruiz et al. (2011), menemukan bahwa kepemimpinan etis organisasi memiliki dampak tidak langsung pada kinerja karyawan. Cristine et al, (2012), menemukan bahwa pertimbangan dan inisiasi struktur perilaku kepemimpinan etis, berhubungan positif dengan kepuasan kerja, dan kepuasan kerja berdampak pada stress terkait pekerjaannya.

Dalam penelitian Elci Meral et al. (2012), dengan menggunakan sampel 1.093 karyawan di 70 perusahaan pada sembilan industri yang berbeda di Turki, ditemukan bahwa kepemimpinan etis dan efektifitas kepemimpinan secara negatif mempengaruhi niat berpindah karyawan, stres terkait kerja memiliki efek positif pada niat berpindah karyawan. Selain itu stres kerja menjadi variabel mediator untuk hubungan yang dihipotesiskan.

Penelitian ini mereplikasi dari penelitian yang dilakukan oleh Elci Meral et al.(2012), yang menguji dampak pemimpin etis, efektivitas pemimpin, dan stress kerja pada niat berpindah karyawan. Alasan mereplikasi penelitian ini karena pengaruh ketiga variabel tersebut masih jarang diteliti di kawasan Asia Tengara, padahal ketiga variabel ini sangat penting bagi keberlangsungan perusahaan. Objek yang digunakan dalam 
Journal of Business Finance and Economic (JBFE)

Volume 1, Nomor 1, Juni 2020

http://journal.univetbantara.ac.id/index.php/jbfe

penelitian ini adalah CV Rimba Sentosa Tawangsari. Alasan memilih CV Rimba Sentosa Tawangsari sebagai objek penelitian ini, karena CV Rimba Sentosa Tawangsari yang bergerak pada bidang mebel ini, niat berpindah karyawannya cukup tinggi. Niat berpindah yang cukup tinggi tersebut memotivasi penulis untuk melakukan penelitian dengan meneliti pemimpin etis, efektivitas pemimpin sebagai variabel independen, stress kerja sebagai variabel mediasi dan niat berpindah karyawan sebagai variabel dependen.

\section{KAJIAN PUSTAKA DAN PERUMUSAN HIPOTESIS}

\section{Pengaruh pemimpin etis pada niat berpindah karyawan}

Rukmana, 2007 dalam Ebrahimi et al. (2016), mengemukakan bahwa pemimpin etis adalah kemampuan dan kesiapan seseorang untuk mempengaruhi dan menuntun seseorang atau kelompok orang, untuk mencapai tujuan bersama dengan menekankan pentingnya nilai-nilai moral. Pemimpin etis dianggap penting secara unik karena pengaruh para pemimpin terhadap perilaku organisasi dan pada akhirnya berpengaruh pada kinerja organisasi (Aronson, 2001; Kanungo, 2001; Trevino et al, 2003 dalam Elci Meral et al,. 2012). Selain itu, kepemimpinan etis diyakini bisa mengarahkan dan membimbing anggota organisasi menuju tujuan dan sasaran, yang menguntungkan organisasi, anggotanya, pemangku kepentingan lainnya, dan masyarakat (Kanungo, 2001). Brown et al. (2005), menggambarkan pemimpin etis sebagai pemimpin yang jujur, dapat dipercaya, adil dan peduli. Pemimpin semacam itu membuat kebijakan dalam lingkungan kerja dengan berprinsip adil. Sejalan dengan Brown et al. 2005, penulis melihat perilaku adil dan bermoral dari para pemimpin sebagai komponen inti dari kepemimpinan etis, dan penulis memberi label pada komponen kepemimpinan etis ini, sebagai perhatian terhadap moralitas dan keadilan. Singkatnya, orang membedakan moralitas dan keadilan, klarifikasi peran etis dan pembagian kekuasaan sebagai komponen kepemimpinan etis di tempat kerja (De Hoogh dan Den Hartog, 2008 dalam Elci Meral et al. 2012). Hasil dari penelitian sebelumnya menunjukkan, bahwa pemimpin etis berpengaruh negatif terhadap niat perpindahan karyawan (Elci Meral et al. 2012). Ikatan antara pemimpin etis dan karyawan yang baik, menciptakan lingkungan yang menyenangkan di tempat kerja. Hal ini menyebabkan komitmen yang lebih tinggi dan mengurangi niat berpindah karyawan (Mulki et al, 2007 dalam Elci Meral et al. 2012). Dengan demikian, hipotesis yang dirumuskan adalah: 
Journal of Business Finance and Economic (JBFE)

Volume 1, Nomor 1, Juni 2020

http://journal.univetbantara.ac.id/index.php/jbfe

Hipotesis 1 : Pemimpin etis berpengaruh negatif pada niat berpindah karyawan.

\section{Pengaruh efektivitas pemimpin pada niat berpindah karyawan}

Efektivitas pemimpin adalah pemimpin yang mampu menjalankan fungsinya dengan baik, memberi manfaat bagi organisasi, seperti menjaga reputasi organisasi dengan baik, selalu memotivasi bawahannya, meningkatkan keuntungan organisasi (Fazialdi, 2013). Kepemimpinan sangat penting dalam setiap organisasi, pemimpin yang baik akan menyebabkan kelancaran fungsi organisasi, karyawan termotivasi dan secara keseluruhan efektif dalam kinerja organisasi (Bus. et al,2015). Hasil dari penelitian sebelumnya yang dilakukan oleh Elci Meral et al., (2012), menunjukkan bahwa efektivitas pemimpin berpengaruh negatif pada niat perpindahan karyawan. Dengan demikian, hipotesis yang dirumuskan adalah:

Hipotesis 2 : Efektivitas pemimpin berpengaruh negatif pada niat berpindah karyawan.

\section{Pengaruh stress kerja pada niat berpindah karyawan}

Handoko (2010), mengemukakan stres adalah suatu kondisi ketegangan yang mempengaruhi emosi, proses berfikir dan kondisi seseorang. Menurut Gibson et al., (2011), Stress kerja adalah suatu tanggapan penyesuaian, diperantarai oleh perbedaan-perbedaan dari individu-individu dan atau proses-proses psikologis, akibat dari setiap tindakan timbal balik, situasi atau peristiwa yang membutuhkan psikologi dan atau fisik berlebihan kepada seseorang. Menurut Suwatno dan Priansa (2011), stress kerja adalah suatu kondisi dimana terdapat satu atau beberapa faktor di tempat kerja yang berinteraksi dengan pekerja, sehingga mengganggu kondisi fisiologis dan perilaku. Stress kerja akan muncul bila terdapat kesenjangan antara kemampuan individu dengan tuntutan-tuntutan dari pekerjaannya. Menurut Notoadmojo dalam Haryanti (2013) stress dapat terjadi pada hampir semua pekerja, baik tingkat pimpinan maupun pelaksana. Kondisi kerja yang lingkungannya tidak baik, sangat potensial untuk menimbulkan stres bagi pekerjanya.Stres di lingkungan kerja memang tidak bisa dihindari, yang dapat dilakukan adalah mengelola, mengatasi, atau mencegah terjadinya stres tersebut, sehingga tidak menimbulkan ketidakpuasan dalam pekerjaan, yang pada akhirnya dapat menimbulkan turnover karyawan. Hasil dari penelitian sebelumnya menunjukkan bahwa stress kerja berpengaruh positif terhadap niat perpindahan karyawan. Elci Meral. et al,. (2012). Penelitian juga dilakukan oleh Andini Oktarini P. et al (2018) yang menunjukkan bahwa stress kerja 
Journal of Business Finance and Economic (JBFE)

Volume 1, Nomor 1, Juni 2020

http://journal.univetbantara.ac.id/index.php/jbfe

berpengaruh positif terhadap niat perpindahan karyawan. Dengan demikin, hipotesis yang dirumuskan adalah:

Hipotesis 3: Stress kerja berpengaruh positif pada niat berpindah karyawan.

\section{Pengaruh pemimpin etis pada stress kerja}

Brown et al. (2005), berpendapat bahwa pemimpin etis transparan dan terlibat dalam komunikasi terbuka, meningkatkan dan menghargai perilaku etis di kalangan bawahannya. Brown mendefinisikan kepemimpinan etis sebagai "demonstrasi perilaku normatif yang sesuai aturan-aturan, melalui tindakan pribadi dan hubungan interpersonal, dan peningkatan perilaku semacam itu kepada bawahannya melalui komunikasi dua arah, penguatan, dan pengambilan keputusan". Hasil penelitian sebelumnya yang dilakukan Elci Meral et al,. (2012), menunjukkan bahwa pemimpin etis berpengaruh negatif pada stress kerja. Dengan demikian hipotesis yang dirumuskan adalah:

Hipotesis 4: Pemimpin etis berpengaruh negatif pada stress kerja.

\section{Pengaruh efektivitas pemimpin pada stress kerja}

Pemimpin sangat penting dalam setiap organisasi, pemimpin yang baik akan menyebabkan kelancaran fungsi-fungsi dalam organisasi, karyawan menjadi termotivasi dan secara keseluruhan efektif dalam kinerja organisasi (John \& Chattopadhyay, 2015). Efektivitas pemimpin ditunjukkan dari profesionalisme seorang pemimpin yang sesuai dengan posisi dan eksistensi organisasinya, dimana pemimpin dituntut untuk menguasai berbagai apek manajerial yang berkaitan dengan perilaku organisasinya, karena dengan memahami aspek manajerial tersebut dapat digunakan untuk menopang tugas utama pemimpin baik dalam berpikir secara konsepsional, membina kreativitas, mewujudkan kondisi organisasi yang harmonis, maupun ketika dirinya mengintegrasikan antara aspek struktur, proses, teknologi dan manusia (Sujak, 2009). Hasil penelitian sebelumnya yang dilakukan Elci Meral et al. (2012) menunjukkan bahwa efektivitas pemimpin berpengaruh negatif pada stress kerja. Dengan demikian hipotesis yang dirumuskan adalah:

Hipotesis 5: Efektivitas pemimpin berpengaruh negatif pada stress kerja.

Berdasarkan hipotesis yang dirumuskan, pengaruh antar variabel dapat digambarkan dalam bentuk model penelitian sebagai berikut :

\section{Pemimpin Etis}


Journal of Business Finance and Economic (JBFE)

Volume 1, Nomor 1, Juni 2020

http://journal.univetbantara.ac.id/index.php/jbfe

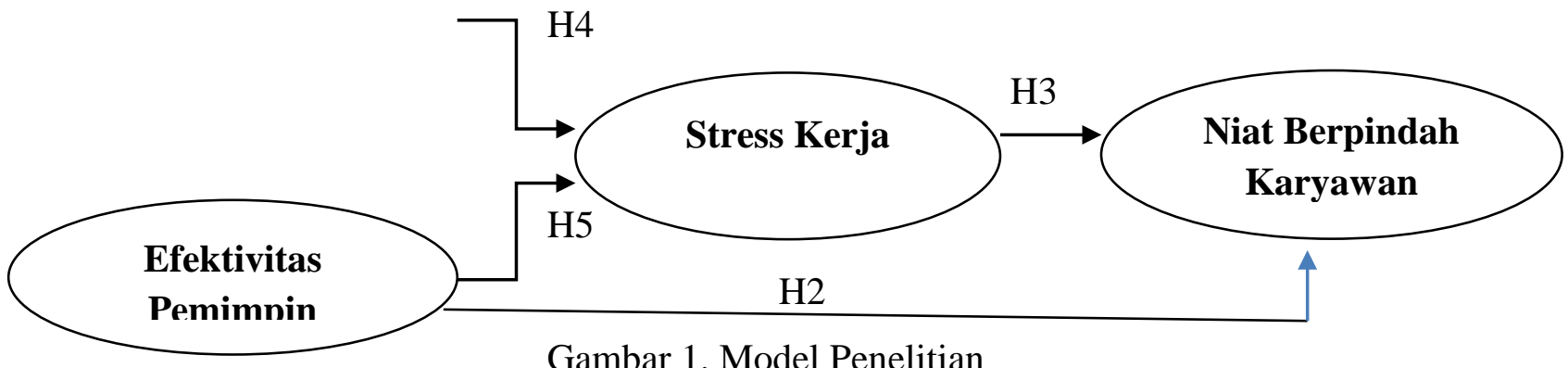

Gambar 1. Model Penelitian

\section{METODA PENELITIAN}

\section{Populasi dan Sampel}

Populasi dalam penelitian ini adalah 180 karyawan di CV. Rimba Sentosa Tawangsari, Sampel yang digunakan adalah karyawan CV. Rimba Sentosa Tawangsari sebanyak 115. Pengambilan sampel dalam penelitian ini menggunakan desain nonprobability sampling dengan metodeconvenience sampling yaitu pengambilan sampel yang dilakukan dengan mengambil sampel dari populasi berdasarkan kemudahan (Sekaran\& Bougie, 2009).Untuk teknik analisis yang digunakan dalam penelitian ini adalah teknik Analisis SEM (structural equation modelling. Kuesioner yang dibagikan sebanyak 150 dan hanya kembali 129 kuesioner, setelah dilihat ada 115 kuesioner yang lengkap dan layak untuk diolah.

Tabel 1

Karakteristik Responden

\begin{tabular}{lcc}
\hline \multicolumn{1}{c}{ Karakteristik } & Frekuensi & Persentase (\%) \\
\hline Laki-laki & Jenis kelamin & \\
Perempuan & 71 & 61.7 \\
& 44 & 38.3 \\
18 tahun s/d 30 tahun & Usia & 73.9 \\
31 tahun s/d 40 tahun & 85 & 21.7 \\
41 tahun s/d 50 tahun & 25 & 4.3 \\
& 5 & \\
6 bulan s/d 10 tahun & Masa Kerja & 90.4 \\
11 tahun s/d 20 tahun & 104 & 7.8 \\
21 tahun s/d 30 tahun & 2 & 1.7 \\
& Pendidikan & \\
SD & Terakhir & 1.7 \\
SMP & 2 & 19.1 \\
SMA/SMK & 22 & 76.5 \\
D3 & 38 & 2.6 \\
\hline
\end{tabular}


Journal of Business Finance and Economic (JBFE)

Volume 1, Nomor 1, Juni 2020

http://journal.univetbantara.ac.id/index.php/jbfe

\section{Definisi Operasional dan Pengukuran Variabel}

Untuk memberikan gambaran dan pemahaman yang lebih baik, maka berikut ini akan disampaikan definisi operasional dari masing-masing variabel yang berkaitan dan akan dibahas dalam penelitian ini. Setiap item pernyataan yang digunakan dalam penelitian ini dinilai dengan menggunakan Skala Likert dengan 5 alternatif pilihan, yaitu Sangat Tidak Setuju (STS), Tidak Setuju (TS), Netral (N), Setuju (S) dan Sangat Setuju (SS).

\section{Efektivitas Pemimpin}

Efektivitas pemimpin adalah pemimpin yang mampu menjalankan fungsinya dengan baik dengan memberikan manfaat bagi organisasi seperti menjaga reputasi organisasi yang baik, selalu memotivasi bawahannya, meningkatkan keuntungan untuk organisasi, Fazialdi (2013). Pengukuran sikap dalam penelitian ini menggunakan 4 item pernyataan yang diadopsi dari Sener et al. (2012).

\section{Stres Kerja}

Stres adalah ketegangan atau tekanan emosional yang dialami sesesorang yang sedang menghadapi tuntutan yang sangat besar, hambatan-hambatan, dan adanya kesempatan yang sangat penting yang dapat mempengaruhi emosi, pikiran dan kondisi fisik seseorang. Stres tersebut akan muncul apabila ada tuntutan-tuntutan pada seseorang yang dirasakan menekan, membebani atau melebihi daya penyesuaian yang dimiliki individu, Wijono (2006). Pengukuran sikap dalam penelitian ini menggunakan 6 item pernyataan yang diadopsi dari Sener et al. (2012).

\section{Niat Berpindah Karyawan}

Niat berpindah adalah kecenderungan atau intensitas individu untuk meninggalkan organisasi atau perusahaan dengan berbagai alasan, diantaranya keinginan untuk mendapatkan pekerjaan yang lebih baik (Ronald dan Milkha, 2014). Menurut Allen (2004), niat berpindah kerja merupakan keinginan berhenti dari suatu perusahaan dan pindah kerja ke perusahaan lain dengan alasan tertentu. Pengukuran sikap dalam penelitian ini menggunakan 3 item pernyataan yang diadopsi dari Sener.et al,. (2012).

\section{HASIL DAN PEMBAHASAN}

\section{Hasil Uji Instrumen Penelitian}

Pengujian validitas dilakukan pada empat variabel utama dalam penelitian ini, yaitu pemimpin etis, efektivitas pemimpin, stress kerja dan niat berpindah karyawan. Hasil uji validitas menunjukkan satu item yang tidak valid sehingga dihilangkan pada proses berikutnya, yaitu item pernyataan pemimpin etis dan stress kerja. 
Journal of Business Finance and Economic (JBFE)

Volume 1, Nomor 1, Juni 2020

http://journal.univetbantara.ac.id/index.php/jbfe

Uji reliabilitas yang dilakukan menghasilkan nilai Cronbach's alpha pemimpin etis sebesar 0,885, efektivitas pemimpin 0,845, stress kerja 0,837, niat berpindah karyawan 0,907.

\section{Hasil Uji Hipotesis}

Untuk menguji hipotesis dalam penelitian ini menggunakan metode SEM (Structural Equation Modeling). Hal-hal yang perlu diperhatikan dalam melakukan pengujian dengan pendekatan SEM, yaitu analisis kesesuaian model dan analisis koefisien jalur. Hasil dari masing-masing analisis adalah sebagai berikut:

Tabel 2.

Hasil Goodness-of-Fit Model

\begin{tabular}{|c|c|c|c|}
\hline \\
\hline \multicolumn{4}{|c|}{ 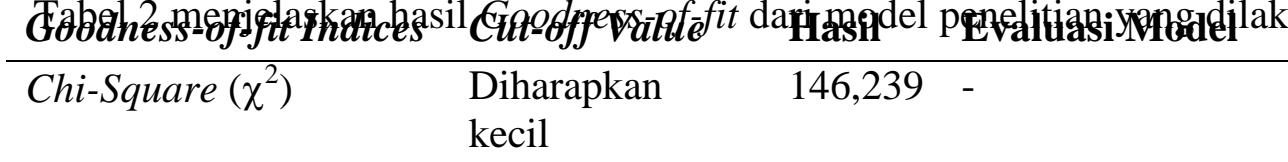 } \\
\hline \multicolumn{4}{|c|}{$\begin{array}{llll}\text { Degrees of freedom } & \text { Positif } & 139 & \text { Fit }\end{array}$} \\
\hline Probability level ( $p)$ & $\geq 0,05$ & 0,320 & Belum Memenuhi \\
\hline$C M I N / D F$ & $\leq 2,0$ & 1,052 & Fit \\
\hline GFI & $\geq 0,90$ & 0,888 & Belum Memenuhi \\
\hline AGFI & $\geq 0,90$ & 0,848 & Belum Memenuhi \\
\hline$T L I$ & $\geq 0,90$ & 0,993 & Fit \\
\hline CFI & $\geq 0,90$ & 0,994 & Fit \\
\hline RMSEA & $\leq 0,08$ & 0,021 & Fit \\
\hline
\end{tabular}

sehingga diperlukan indikator-indikator lainnya untuk menghasilkan suatu justifikasi yang pasti mengenai kesesuaian model (Ferdinand, 2006). Nilai CMIN/DF, TLI, CFI dan RMSEA dalam penelitian ini menunjukkan tingkat kesesuaian yang baik, sedangkan GFI dan AGFI dalam penelitian ini menunjukkan tingkat kesesuaian yang kurang baik.

\section{Analisis Regression Weights}

Tabel 3 menunjukkan hasil pengujian pemimpin etis, efektivitas pemimpin sebagai variabel independen, stress kerja sebagai variabel mediasi, dan niat berpindah karyawan sebagai variabel dependen.

Tabel 3.

Regression Weights

\begin{tabular}{lll|rrrr}
\hline & & & Estimate & S.E. & C.R. & P \\
\hline Stress kerja & $<---$ & Pemimpin etis &, 059 &, 165 &, 357 &, 721 \\
Stress kerja & $<---$ & Efektivitas &, 090 &, 098 &, 917 &, 359
\end{tabular}




\begin{tabular}{|c|c|c|c|c|c|c|}
\hline & & & Estimate & S.E. & C.R. & $\mathbf{P}$ \\
\hline Niat berpindah & $<---$ & $\begin{array}{l}\text { pemimpin } \\
\text { Efektivitas } \\
\text { pemimpin }\end{array}$ & ,303 & ,116 & 2,600 & 009, \\
\hline Niat berpindah & $<---$ & Pemimpin etis & ,066 & 191 & 344 & ,731 \\
\hline Niat berpindah & $<---$ & Stress kerja & ,055 & ,119 & ,460 & ,645 \\
\hline
\end{tabular}

Hasilnya untuk pengaruh pemimpin etis terhadap niat berpindah karyawan, memiliki hasil yang tidak signifikan yaitu 0,731, maka H1 tidak didukung. Pengaruh efektivitas pemimpin terhadap niat berpindah karyawan, memiliki hasil yang signifikan yaitu 0,009, maka H2 didukung. Pengaruh stress kerja terhadap niat berpindah karyawan, memiliki hasil yang tidak signifikan yaitu 0,645, maka H3 tidak didukung. Pengaruh pemimpin etis terhadap stress kerja, memiliki hasil yang tidak signifikan yaitu 0,721, maka H4 tidak didukung. Pengaruh efektivitas pemimpin terhadap stress kerja, memiliki hasil yang tidak signifikan yaitu 0,359, maka H5 tidak didukung.

\section{PEMBAHASAN}

\section{Pengaruh Pemimpin Etis pada Niat Berpindah Karyawan}

Hasil dari penelitian ini menunjukkan bahwa pemimpin etis tidak berpengaruh pada niat berpindah karyawan. Dalam organisai ini pemimpin yang bermoral tidak mempengaruhi niat berpindah karyawan, mungkin dikarenakan kurang adanya kedekatan antara pemimpin dengan bawahannya, sehingga karyawan kurang paham dan peduli dengan sikap moral pemimpinnya, kemungkinan lain karyawan hanya berfikir untuk bekerja saja kemudian mendapatkan gaji untuk memenuhi kebutuhan sehari-hari tanpa memikirkan hal tersebut. Oleh karena itu pemimpin yang etis ataupun pemimpin yang tidak etis, tidak akan mempengaruhi niat berpindah karyawan. Hasil penelitian ini mendukung penelitian yang dilakukan oleh Elci Meral., et al. (2012) bahwa pemimpin etis tidak berpengaruh pada niat berpindah karyawan.

\section{Pengaruh Efektivitas Pemimpin pada Niat Berpindah Karyawan}

Hasil dari penelitian ini menunjukkan bahwa efektivitas pemimpin, berpengaruh pada niat berpindah karyawan. Pada CV Rimba Sentosa Tawangsari, pemimpin yang dapat menentukan tujuan organisasi dengan tepat, mampu menggerakkan dan memotivasi bawahannya untuk mencapai tujuan yang telah ditetapkan, pemimpin yang mampu menjaga reputasi perusahaan dengan baik dan mampu meningkatkan keuntungan perusahaan, akan mengurangi niat berpindah karyawan. Sebaliknya, 
Journal of Business Finance and Economic (JBFE)

Volume 1, Nomor 1, Juni 2020

http://journal.univetbantara.ac.id/index.php/jbfe

pemimpin yang tidak dapat menentukan tujuan organisasi dengan tepat, tidak dapat menggerakkan bawahannya, tidak dapat memotivasi bawahannya untuk mencapai tujuan yang telah ditetapkan, serta pemimpin yang tidak mampu menjaga reputasi perusahaan dengan baik dan tidak mampu meningkatkan keuntungan perusahaan, akan meningkatkan niat berpindah karyawan. Hal tersebut mungkin dikarenakan para karyawan kurang percaya pada atasannya, dan beranggapan bahwa atasan yang tidak efektif akan menghambat keberlangsungan perusahaan, dan mengancam keberadaan para karyawan di perusahaan tersebut, dan pada akhirnya hal itu memicu timbulnya kekhawatiran akan dilakukan pemutusan hubungan kerja (PHK), jika perusahaan mengalami penurunan omset atau keuntungan, sehingga kekhawatiran yang dirasakan oleh para karyawan tersebut akan mempengaruhi niat berpindah. Hasil penelitian ini tidak mendukung penelitian yang dilakukan oleh Elci Mera et al. (2012), yang mengemukakan bahwa efektivitas pemimpin tidak berpengaruh pada niat berpindah karyawan.

\section{Pengaruh Stress Kerja Pada Niat Berpindah Karyawan}

Hasil dari penelitian ini menunjukkan bahwa stress kerja tidak berpengaruh pada niat berpindah karyawan. Dalam organisasi ini adanya tidak ketidakseimbangan antara tuntutan lingkungan kerja yang dirasakan oleh karyawan dengan kemampuan karyawan untuk memenuhi tuntutan tersebut, tidak mempengaruhi keinginan karyawan untuk meninggalkan perusahaan. Hal ini dimungkinkan karena pentingnya pekerjaan tersebut bagi karyawan, karyawan merasa bahwa pekerjaannya itu adalah satu satunya yang bisa menghasilkan uang yang cukup untuk memenuhi kebutuhan sehari-hari (tidak ada pekerjaan yang lain), mungkin juga karena gaji di CV Rimba Sentosa Tawangsari, di atas rata-rata perusahaan di Tawangsari, serta tidak pernah terlambat dalam pembayaran gaji, dibandingkan dengan perusahaan lain yang sejenis. Oleh karena itu, karyawan akan menyayangkan jika mereka keluar dari perusahaan, sehingga tinggi rendahnya stress kerja yang dirasakan karyawan, tidak akan mempengaruhi niat berpindah/keluar dari perusahaan. Hasil penelitian ini tidak mendukung penelitian yang dilakukan oleh Elci Meral et al. (2012), yang mengungkapkan bahwa stres kerja mempengaruhi niat berpindah karyawan.

\section{Pengaruh Pemimpin Etis pada Stres Kerja}

Hasil dari penelitian ini menunjukkan bahwa pemimpin etis tidak berpengaruh pada stress kerja. Pada CV Rimba Sentosa Tawangsari, pemimpin yang bermoral tidak mempengaruhi stress kerja, mungkin dikarenakan kurang adanya kedekatan antara pemimpin dengan bawahan, sehingga karyawan kurang paham dan peduli 
Journal of Business Finance and Economic (JBFE)

Volume 1, Nomor 1, Juni 2020

http://journal.univetbantara.ac.id/index.php/jbfe

dengan sikap moral pemimpinnya, sehingga pemimpin etis tidak memberikan tuntutan yang berarti bagi karyawan. Kemungkinan lain karyawan bisa saja karyawan mengalami stes kerja, karena memiliki beban/tuntutan yang berat, dan bukan karena faktor dari pemimpin tapi dari pekerjaannya itu sendiri atau faktor lain dari luar perusahaan. Oleh karena itu, pada akhirnya pemimpin etis tidak mempengaruhi stress kerja. Hasil penelitian ini mendukung penelitian yang dilakukan oleh Elci Meral et al. (2012), yang mengemukakan bahwa pemimpin etis tidak berpengaruh pada stress kerja.

\section{Pengaruh Efektivitas Pemimpin pada Stress Kerja}

Hasil dari penelitian menunjukkan bahwa di CV Rimba Sentosa Tawangsari, efektivitas pemimpin tidak berpengaruh pada stress kerja. Pemimpin yang mampu memotivasi bawahan serta mampu meningkatkan keuntungan perusahaan tidak mempengaruhi stress kerja, mungkin dikarenakan kurangnya waktu interaksi ataupun komunikasi yang dilakukan pemimpin pada bawahannya, sehingga karyawan kurang tahu dan peduli dengan efektivitas pemimpinnya, sehingga efektivitas pemimpin tidak memberikan tuntutan yang berarti bagi karyawan dan pada akhirnya efektivitas pemimpin tidak mempengaruhi stress kerja. Hasil penelitian ini mendukung penelitian yang dilakukan oleh Elci Meral et al. (2012), yang mengemukakan bahwa efektivitas pemimpin tidak berpengaruh pada stress kerja.

\section{KESIMPULAN, KETERBATASAN DAN SARAN}

Berdasarkan hasil penelitian ini dapat diambil kesimpulan bahwa variabel efektivitas pemimpin berpengaruh pada niat berpindah karyawan, sedangkan variabel pemimpin etis dan stress kerja tidak berpengaruh pada niat berpindah karyawan. Variabel pemimpin etis dan efektivitas pemimpin tidak berpengaruh pada stress kerja.

Dalam pelaksanaan penyebaran kuesioner terdapat keterbatasan untuk memperoleh informasi karena teknik penyebaran kuesioner tidak dapat diberikan secara langsung oleh responden yang bersangkutan, sehingga peneliti tidak dapat mengetahui respon langsung dari responden. Hal ini karena dapat mengganggu kegiatan di perusahaan Rimba Sentosa Tawangsari, maka kuesioner diserahkan kepada bagian security. Tempat yang digunakan untuk penelitian ini hanya berfokus pada satu perusahaan, sehingga terdapat keterbatasan dalam mengukur niat berpindah karyawan secara umum. Maka belum dapat digunakan sebagai acuan untuk mengukur tinggi rendahnya niat berpindah karyawan di perusahaan lain. 
Journal of Business Finance and Economic (JBFE)

Volume 1, Nomor 1, Juni 2020

http://journal.univetbantara.ac.id/index.php/jbfe

Hasil penelitian ini juga memberikan implikasi bahwa untuk mengurangi niat berpindah karyawan dapat dilakukan dengan keefektivitasan pemimpin. Hal ini dapat dicapai antara lain dengan memotivasi bawahannya sehingga para karyawan semangat dalam menjalankan pekerjaannya, dan pada akhirnya dapat meningkatkan keuntungan bagi perusahaan. 
Journal of Business Finance and Economic (JBFE)

Volume 1, Nomor 1, Juni 2020

http://journal.univetbantara.ac.id/index.php/jbfe

\section{DAFTAR PUSTAKA}

Ansar Muhamad, N. 2017. Pengaruh Kepemimpinan Transformasional Terhadap Kekompakan, Keterlibatan Kerja dan Kinerja Pegawai. Banjarmasin: Jurnal Bisnis dan Pembangunan, Vol 6. No. 1 (2017) ISSN 2541-178X.

Andini Putri, O., Sunuharyo Bambang, S., dan Utami Hamidah, N. 2018. Pengaruh Kepuasan Kerja Terhadap Stress Kerja dan Niat Berpindah Karyawan. Malang: Jurnal Administrasi Bisnis.

Angel Maudul. 2018. Pengaruh pemimpin etis dan budaya organisasi terhadap kinerja karyawan. Jurnal Administrasi Bisnis. Vol. 6 No. 3.

Baskoro aditya. dan Wishnu Ludi, W. 2017. Pengaruh Stress Kerja Terhadap Turnover Intention Pekerja Melalui Kepuasan Kerja di UMKM Pengolahan Tahu Malang. Penataran Vol 2 No. 2 (2017) hlm 119-126.

Birol Baysaka, Müjdelen İ. Yenerb. 2015. The relationship between perceived leadership style and perceived stress on hospital employees. Procedia - Social and Behavioral Sciences. 207 (2015) $79-89$.

Caesarani Christy Angelica. and Gede Riana. 2016. Pengaruh Stress Kerja Terhadap Komitmen Karyawan dan Niat Berpindah Karyawan Pada Sari Segara Resort Villa dan SPA. E-Jurnal Manajemen unud Bali: Universitas Udayana (Unud).

Hamid Reza Rezaei Kelidbari. et.al. 2016. The role of ethical leadership on employee performance in Guilan University of medical sciences. Procedia - Social and Behavioral Sciences. 230 (2016) $463-470$.

Harmoko Heru Sulistyo. 2014. Peran Kepemimpinan Etis dan Pemberdayaan Psikologi Terhadap Kepuasan Untuk Meningkatkan Kinerja Atlet PPLP Sulawesi Tenggara Universitas Islam Sultan Agung Semarang, Jurnal Administrasi Bisnis. Vol.15, No.2, Juli 2014 : $45-54$.

Herawati Jajuk. 2015. Pengaruh Kepemimpinan Etis dan Komitmen Organisasional Terhadap Kinerja Karyawan Koperasi Batik di Yogyakarta. E. Jurnal Manajemen, Universitas Sarjanawiyata Tamansiswa.

Iveta Ozolina-Ozola. 2014. The impact of human resource management practices on employee turnover. Procedia - Social and Behavioral Sciences. 156 (2014) 223 $-226$.

Meral Elci et.al. 2012. The Impact of Ethical Leadership and Leadership Effectiveness on E The Mediating Role of Work Related Stress. Procedia - Social and Behavioral Sciences 58 (2012) 289 - 297.

Meral Elçi. et.al. 2013. The Impacts Of Ethical Leadership On The Antisocial Behavior Of Employess: The Mediating Role Of Ethical Climate. Journal of Global Strategic Management | V. 7 | N. 2 | 2013-December | 57-66.

Panagiotis Trivellasa et.al. 2013. The effect of job related stress on employees' satisfaction: A survey in Health Care. Procedia - Social and Behavioral Sciences. 73 (2013) $718-726$.

Shukurat Moronke Bello. 2012. Impact of Ethical Leadership on Employee Job Performance, International Journal of Business and Social Science Vol. 3 No. 11; June 2012. 
Journal of Business Finance and Economic (JBFE)

Volume 1, Nomor 1, Juni 2020

http://journal.univetbantara.ac.id/index.php/jbfe

Sutanto Eddy, M. dan Gunawan Carin. 2013. Kepuasan Kerja, Komitmen Organisasi dan Niat Berpindah Karyawan. Jurnal Administrasi BisnisSurabaya: Universitas Kristen Petra.

Sukarja Rahmat. dan Machasin. 2015. Pengaruh Kepemimpinan Dan Komunikasi Terhadap Kepuasan Kerja dan Kinerja Pegawai Dinas Pendidikan Provinsi Riau. Riau: Universitas Riau. Jurnal Tepak Manajemen Bisnis. Vol 270. No VII. 2015.

Sumarjaya Bayu, M. dan Supartha I Wayan, G. 2017. Pengaruh Kepemimpinan Etis Terhadap Komitmen Organisasional dan Kepuasan Kerja di Hotel Asana Agung Putra Bali. E. Jurnal Manajemen Unud, Vol 6, no.4, 2017: 1846-1876.

Paripurna I Gede, D. et al. 2017. Pengaruh Kepemimpinan Dan Kepuasan Kerja Terhadap Turnover Intention Serta Dampaknya Terhadap Kinerja Karyawan PT Agung Automall Kuta. Bali: E-Jurnal Ekonomi dan Bisnis Universitas Udayana. Vol 6 No.6 (2017).

Ulman. J.B (2006) SEM, Reviewing the Basics and Moving Forward. Jurnal Of Personality Assesment, 87(1), 35-50. 